\title{
Přístupy k analýze argumentačního textu
}

\author{
Iva Svačinová \\ Filozofická fakulta \\ Univerzita Hradec Králové \\ Rokitanského 62, 50003 Hradec Králové \\ iva.svacinova@uhk.cz
}

\section{1. Úvod}

Před šedesáti lety, $v$ roce 1958, byla publikována dvě díla dnes obecně považovaná za zakládající texty moderní teorie argumentace: Traité de l'argumentation: La nouvelle rhétorique ${ }^{1}$ belgických autorů Chaïma Perelmana a Lucie Olbrechts-Tytecové a The Uses of arguments ${ }^{2}$ amerického filozofa Stephena Toulmina. ${ }^{3}$

Přístup iniciovaný Perelmanem, Olbrechts-Tytecovou a Toulminem vyšel z programového vymezení vůči v té době převládajícímu pojetí, podle nějž je adekvátním přístupem k pochopení argumentace logická analýza. Autoři se ohrazují: logická analýza není dostatečnou analýzou toho, co se $\mathrm{v}$ argumentaci děje. ${ }^{4}$ Argumentace $\mathrm{v}$ jejich pohledu přestává být chápána pouze jako specificky strukturovaný vztah mezi premisami a závěrem, do popředí se dostává pohled na argumentaci jako součást procesu komunikace. V takovém přístupu je nutné zohlednit další - dosud přehlížené - aspekty argumentace, jako je specifický kontext či konverzační situace, v níž je argumentace předkládána, publikum, které je oslovováno, pragmatické cíle, které mluvčí sledují, př́ípadně konkrétní volba lexika či réto-

1 Srovnej Perelman \& Olbrechts-Tyteca (1958).

2 Srovnej Toulmin (1958).

3 Srovnej van Eemeren (2009, s. 20).

4 Srovnej Perelman \& Olbrechts-Tyteca (1969, s. 13), Toulmin (1976, s. vi). 
rických prostředků, které mluvčí při předkládaní argumentace využívají. Na program vymezený Perelmanem, Olbrechts-Tytecovou a Toulminem navazuje od sedmdesátých let řada autorů, kteří rozvíjejí teoretické systémy k zachycení těchto aspektů argumentace a analytické nástroje, které jim umožňují zkoumat a popsat specifika přesvědčování.

Textů, které by v českém prostředí reflektovaly vývoj a výdobytky moderních př́stupů $\mathrm{k}$ analýze argumentace a seznamovaly s nimi čtenáře, je ovšem zatím málo. ${ }^{5}$ Rozhodli jsme se tedy tuto pomyslnou mezeru zaplnit v rámci čísla Filosofie dnes.

Monotematické číslo Př́stupy k analýze argumentačního textu jsme připravili ze dvou důvodů. ${ }^{6}$ Prvním motivem je snaha nabídnout čtenářum možnost sledovat zblízka aplikaci několika konkrétních analytických přístupů na konkrétním materiálu. Pokoušíme se vést čtenáře jednotlivými fázemi procesu výzkumu argumentace, ukazujeme, jak je možné pracovat s konkrétními sadami analytických nástrojů. Zároveň se pokoušíme ukázat, že tento proces může být často komplikovaný různými okolnostmi (specifický kontext, vágně formulovaná argumentace, vizuální složka argumentace, humor, jazykové prostředky) a může vyžadovat specifické interpretační vklady, kreativní řešení a konkrétní metodologická rozhodnutí.

Druhým motivem je snaha nabídnout čtenářùm možnost porovnat různé př́stupy k analýze argumentačního textu a zvolit ten nejvhodnější pro účely vlastního výzkumu. Tomuto cíli je podřízena struktura jednotlivých příspěvků. Čtenáři se dozvědí, jak jednotlivé přístupy formulují výzkumné otázky, jaké klíčové teoretické pojmy a nástroje analýzy propracovávají, jakým způsobem identifikují argument v datech, jakým operacím jej podrobují $v$ průběhu rekonstrukce a analýzy.

Monotematické číslo se skládá z pěti př́ispěvkủ, které jsou věnovány neoaristotelskému přístupu (Marek Picha), Toulminově modelu (Tomáš Ondráček), přístupu neformální logiky a konkrétně Douglase Waltona (Martin Prokop), pragma-dialektickému přístupu (Iva Svačinová) a kri-

5 Srovnej např. Klein (2007), Picha (2014).

6 Jako inspirační zdroj pro formu tohoto čísla nám posloužily publikace Kvalitativní analýza textů: čtyři prŕstupy (řiháček et al. 2013) a Five ways of doing qualitative analysis (Wertz et al. 2011), jejichž cílem je rovněž komparace analytických přístupů prostřednictvím aplikace nástrojů na stejný materiál. 
tické diskurzivní analýze (Kateřina Kirkosová). Tyto př́istupy byly vybrány proto, že akcentují odlišné aspekty argumentace nebo šířeji persvaze: její rétorickou, strukturální, dialogickou či lingvistickou dimenzi.

Každý z př́ispěvků stručně představuje východiska daného přístupu, typické výzkumné otázky, obecné principy identifikace, rekonstrukce a analýzy argumentace či jejího konkrétního aspektu. Zároveň klademe důraz na ukázku konkrétní analýzy s využitím představených nástrojů. Aby lépe vynikla možnost porovnat proces i výsledek analýzy, použili jsme pro analýzy ve všech př́ispěvcích stejný empirický materiál. Jako dostatečně zajímavý, pestrý a atraktivní materiál pro účely ilustrativních analýz jsme zvolili video Přemluv bábu z roku 2010. Jedná se o spot, v němž herci Jiř́i Mádl a Martha Issová apelují na mladé diváky, aby přesvědčili své prarodiče $\mathrm{k}$ volbě pravicových stran.7

V následujících kapitolách se věnujeme představení tohoto materiálu. V kapitole 1.1 je nabídnut přepis videa, v kapitole 1.2 stručně shrnujeme historické okolnosti vzniku videa. Kapitola 1.3 je věnována zhodnocení úspěšnosti videa.

\subsection{Přemluv bábu: Představení materiálu}

Video Přemluv bábu bylo publikováno na Youtube 22. dubna 2010, tedy zhruba měsíc před plánovanými volbami do Poslanecké sněmovny. Režie se ujal Petr Zelenka, hlavními protagonisty videa jsou herci Jiří Mádl a Martha Issová. ${ }^{8}$ Autoři videa se netajili inspirací videem The Great Schlep komičky Sarah Silvermanové, která využila podobný scénář v roce 2008. ${ }^{9}$ Silvermanová s cílem podpořit v prezidentských volbách kandidáta Baracka Obamu nabádala k návštěvě prarodičủ Američany židovského původu.$^{10}$ Autoři Přemluv bábu ve svých vyjádřeních deklarovali, že jejich iniciativa není spojena s žádnou konkrétní politickou stranou a vznikla jako osobní reakce na nespokojenost se stavem české politické scény. ${ }^{11}$

7 Srovnej Issová, Mádl \& Zelenka (2010).

8 Srovnej ČSFD (2018).

9 Srovnej Anýž et al. (2010), Krupka (2010).

10 Srovnej Silverman (2008).

11 Srovnej Kratochvíl \& Procházková (2010). 
Klip trvá asi čtyři minuty. Mádl a Issová mluví hovorovou češtinou, využívají dvojsmyslné narážky, vulgarismy, černý humor. Repliky videa jsou doprovázeny řadou vizuálních prostředků (fotografie, obrázky, grafy, nápisy), jejichž prostřednictvím autoři ilustrují, případně ironizují svá tvrzení.

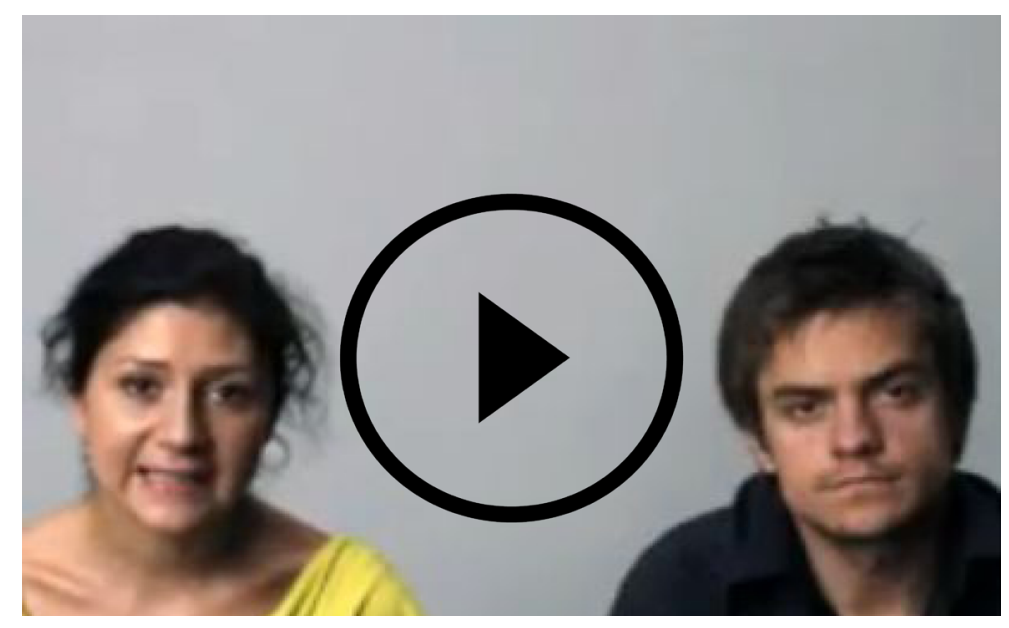

https://www.youtube.com/watch?v=MLfFhdcXJhA

Přepis textu videa

Martha Issová: „Kdybyste věděli, že můžete změnit osud týhle země tím, že navštívíte svoje prarodiče, zajeli byste za nima? No jasně, že jo. Teda pokud nejste úplně...[vypípáno] Já jsem Martha Issová. Přemluv bábu!“

Jiří Mádl: „A taky přemluv dědu!“

M.I.: „To je Jirka Mádl. Jestli v týhle zemi zvítězí u př́štích voleb levice, tak za to budou moct starý lidi, protože to jsou ty, který levici volej. To můžou bejt lidi z vaší rodiny. To může bejt vaše teta, váš strejda, vaše babička..."

J.M.: „...váš děda.“

M.I.: „No. A většinou ty lidi bydlej na vesnici. Jak je to možný?“ 
J.M.: „Prostě se tam narodili!“

M.I.: „Ne, jak je možný, že tu levici volej? Copak voni zapomněli, jak to tady těch čtyřicet let, co byli komunisti u moci, vypadalo?"

J.M.: „Starý lidi mají totiž tzv. selektivní pamět. To znamená, že si pamatujou jenom ty hezký věci. Jak si dali poprvé pusu na taneční zábavě, ale už třeba úplně zapomněli na proces s Miladou Horákovou... Ne, to je Rita Hayworthová.“

M.I.: „Komunisti přinutili nejlepší lidi týhletý země k emigraci Miloše Formana... Miloše Formana, Navrátilovou, Kunderu... Milana Kunderu. My natáčíme tohleto video, abysme vás přesvědčili, že se prostě máte sebrat, koupit si lístek na autobus nebo na vlak nebo nasednout do auta a rozjet se za svejma prarodičema nebo rodičema na venkov a přesvědčit je, že mají volit pravici.“

J.M.: „Nebo nějakou novou stranu.“

M.I.: „No nějakou novou pravicovou stranu a pravice je tohle.“

J.M.: „No ale pro ně je to vobráceně.“

M.I.: „Pravou ruku všude na světě lidi používaj k pozdravu nebo k přijímání potravy a levou rukou si lidi všude na světe vytíraj zadek.“

J.M.: „No v některých zemích...“

M.I.: „No, hlavně když budete volit levici, tak si pak levice vytře zadek s váma.“

J.M.: „Starý lidi argumentujou tím, že volí levici kvůli vám - svým dětem a vnukům. Takže je potřeba jim dát najevo, že kvưli vám socialisty a komunisty rozhodně volit nemaj. Naopak. Volit levici je v přímým rozporu se zájmy jejich potomků.“

M.I.: „Protože levice nadělá dluhy, a zatímco voni si v klidu umřou, tak my je pak budeme do konce života splácet.“

J.M.: „Jo, a jestli někdo volí levici kvůli 3oKč poplatku, dobře, ale je to teda dost sobecký rozhodnutí, který třeba mě poškodí.“ 
M.I.: „Navíc levice nechce řešit problémy s důchody a, pokud nedojde $\mathrm{k}$ reformě, tak ve státní kase nebudou na důchody peníze. A kdo nebude mít našetřeno, ten na tom bude hodně špatně. Ale to levici nezajímá, protože její voliči jsou starý dneska a ne za čtyřicet let.“

J.M.: „Levice nepřipustí školný, oni totiž rádi hlásaj, že to jakože znepřístupní vzdělání chudším. Jenže to je úplná blbost. Naopak. Vzdělávání u nás v Čechách není moc dobrý, a pokud nedokážeme motivovat školy, aby s tím něco dělaly, tak nám ty nejlepší studenti budou odcházet do zahraničí. Když nezafunguje zdravej rozum, použijte nátlak. Pro prarodiče jsou jejich vnoučata to nejdůležitější na světě, takže když budou volit pravici, dostanou od vás jednu návštěvu letos zdarma.“

M.I.: „A když né, no tak doufejme, že budou ještě naživu, až příště přijedete.“

J.M.: „A odměna pro vás, když přemluvíte svoji babičku a svýho dědu?"

M.I.: „Poradíme vám, kde na netu najít úplně zadarmo to nejlepší animální anální porno se členkou italský parlamentní strany, Rocco Siffredim a úhořem."

Oba: „Ale nejdřrív - Přemluv bábu! Přemluv dědu!“

\subsection{Přemluv bábu v politickém kontextu}

Vzhledem $\mathrm{k}$ tomu, že tvưrci videa chtěli posílit volební výsledek pravicových stran, zdá se vhodné stručně si připomenout politickou situaci předcházející volbám v roce 2010 a dosadit tak jejich pokus do bezprostředního kontextu.

Mezi lety 2007 a 2009 vládla České republice pravicová vláda Mirka Topolánka tvořená koalicí stran ODS, KDU-ČSL a SZ. Asi nejzásadnějším projektem vládnoucí koalice byla nepř́iliš populární reforma veřejných financí, jejíž součástí bylo např. snížení přímých a zvýšení nepř́ímých daní, zavedení ekologické daně nebo poplatků ve zdravotnictví. ${ }^{12}$

12 Srovnej Mates (2007). 
Připomeňme, že v prvním pololetí roku 2009 tato vláda předsedala Evropské unii. Opoziční strany ČSSD a KSČM se vládě celkem pětkrát pokusily vyslovit nedůvěru. Povedlo se jim to při pátém pokusu 24. března 2009, kdy pro vyslovení nedůvěry hlasovali i dva poslanci ODS a dvě poslankyně SZ. ${ }^{13}$ Topolánkova vláda byla následně nahrazena překlenovací úřednickou vládou Jana Fischera složenou z nestraníků, která vedla zemi až do voleb na jaře roku 2010. ${ }^{14}$

Předvolební průzkumy v roce 2010 favorizovaly levicové strany ČSSD vedené Jiřím Paroubkem předpovídaly až třicet procent hlasů, očekávaný výsledek KSČM byl kolem dvanácti procent. Oproti tomu ODS, která byla poznamenána skandály spojenými s postavou Mirka Topolánka, odhadovaly průzkumy asi devatenáct procent, TOPog kolem deseti procent, KDU-ČSL měla očekávaný výsledek kolem čtyř procent a Strana zelených asi tři procenta, účast KDU-ČSL a SZ v Poslanecké sněmovně byla tedy nejistá. Významným novým hráčem voleb byla populistická strana Věci veřejné (VV), jejíž stranická profilace však nebyla snadno rozpoznatelná a jejíž výsledek průzkumy odhadovaly na devět procent. ${ }^{15}$

Očekávaný poměr sil levice a pravice byl tedy před volbami 2010 vyrovnaný. Připomeňme však, že pravicové strany dlouhodobě poukazovaly na potenciální nebezpečí vzniku spojenectví ČSSD a KSČM (označované jako „KSČSSD“) a možnost prolomení bohumínského usnesení zakazujícího spolupráci s komunistickou stranou, v př́padě, že by levicové strany společně získaly nadpoloviční většinu hlasư. ${ }^{16}$

Video Přemluv bábu pracuje se spojením staří lidé - voliči levice a mladí lidé - voliči pravice. Toto spojení je pro českou společnost poměrně př́hodné: pravděpodobnost, že je někdo voličem pravice nebo naopak levice, je v České republice do velké míry dána prŕslušností $\mathrm{k}$ věkové kategorii. Již ve volbách do Poslanecké sněmovny v roce 2006 se projevuje trend, podle něhož v ČR mladí lidé mají dlouhodobě ten-

\footnotetext{
13 Srovnej Pobořilová (2009).

14 Srovnej Prokop \& Ř́hová (2009).

15 Srovnej STEM (2010).

16 Srovnej Komárek (2006), Pehe (2009). Stojí za připomínku, že ODS na tomto motivu v roce 2006 založila své předvolební spoty.
} 
denci volit spíše pravici a starší generace volit levicové strany ${ }^{17}$ Pokračování tohoto trendu přitom bylo očekáváno i ve volbách v roce 2010.

Volby do Poslanecké sněmovny proběhly 28.-29. května 2010. Vítězem voleb se stali sociální demokraté s dvaceti dvěma procenty hlasů, těsně následovaní občanskými demokraty s dvaceti procenty hlasů. Vzhledem k tomu, že vítězná ČSSD nebyla schopna utvořit koalici, byl sestavením vlády pověřen lídr ODS Petr Nečas. Koaliční vláda byla sestavena ze stran ODS, TOPo9 a VV, jmenována byla 13. července 2010. ${ }^{18}$

\subsection{Přemluv bábu: Úspěšné nebo neúspěšné přesvědčování?}

Můžeme video Přemluv bábu považovat za úspěšný počin? Odpovědi odborníků se různí v závislosti na tom, jaká kritéria úspěchu při zodpovídání otázky preferují. Někteří hodnotí video z marketingového hlediska jako počin veskrze úspěšný: úspěch přitom chápou jako naplnění jistých očekávání ohledně počtu shlédnutí, rychlosti rozšíření, či vyvolání zájmu, která se pojí s tzv. virálními videi. $Z$ tohoto hlediska je možné spot Přemluv bábu hodnotit jako jeden z nejvýraznějších fenoménů českých předvolebních kampaní. K listopadu 2018 mělo video přes 897 tisíc zhlédnutí, Google vyhledávač nabízí u hesla „Přemluv bábu“ kolem 50 tisíc výsledků. ${ }^{19}$

Video bylo úspěšné i v tom, že velmi rychle získalo zájem médií: bezprostř̌edně po jeho zveřejnění o něm referovala většina českých tištěných i internetových médií. Získalo rychlou odezvu i ze strany politické reprezentace: hned v prvním týdnu se $\mathrm{k}$ němu vyjádřila většina politických stran - představitelé levicových stran video odsoudili, představitelé pravice hodnotili video mírněji. Klip získal velký ohlas ve veřejných diskuzích na sociálních sítích i diskuzních fórech. ${ }^{20}$

17 Srovnej Lebeda et al. (2007, s. 6-7).

18 Srovnej Kopecký (2010).

19 Srovnej Vidovićová \& Honelová (2018, s. 208).

20 Srovnej Budínský (2010, s. 62), Vidovićová \& Honelová (2018, s. 208). Video prokázalo svůj silný virální potenciál. Ten můžeme mimo jiné dovozovat i z řady parodií, které v př́mé návaznosti na video vznikaly (srovnej Budínský 2010, s. 63). Zmínit můžeme video Zabij bábu autorů Janka Rubeše a Čenka Stýbla, v němž je původní sdělení dovedeno do extrému a autoři v nadsázce nabádají mladé diváky k zabití prarodičůn, aby jim zabránili ve volbě levice (srovnej [Rubeš \& Stýblo] 2010), nebo video Ondřeje Lišky a Jiřiny Šiklové, v němž využívají ohlas videa a pokoušejí se zužitkovat jej při přesvědčování k volbě Strany zelených (Liška \& Šiklová 2010). 
Můžeme se však ptát, zda bylo video úspěšné i z hlediska naplnění deklarovaného cíle videa, tj. zda přispělo ke změně poměru voličských preferencí u starší generace nebo zda posílilo účast mladých voličů u voleb. Na první část otázky můžeme odpovědět záporně: u voleb v roce 2010 nedochází $\mathrm{k}$ výrazné změně $\mathrm{v}$ rozložení podpory stran vzhledem $\mathrm{k}$ věku voličů: i ve volbách $\mathrm{v}$ roce 2010 stále platí, že $\mathrm{s}$ vyšším věkem roste pravděpodobnost volby levicové strany: nedochází k odlivu nebo přesunu starších voličů k pravici. ${ }^{21}$

Chápeme-li však video jako součást strategie mobilizovat mladé lidi $\mathrm{k}$ účasti u voleb, pak můžeme opatrně hovořit o úspěchu, $\mathrm{v}$ roce 2010 dochází $\mathrm{k}$ nárůstu volební účasti $\mathrm{u}$ skupiny mladých voličů: u věkové skupiny 18-29 let se zvýšila ze 47 na $52 \%$. Zajímavé je i to, že zároveň klesá účast u věkové skupiny $50-59$ let z 68 na $63 \%$. Ze změny struktury volební účasti profitovala především TOP 09 a VV. Podle Lukáše Linka však rozhodně nelze mluvit o tom, že by „mladí rozhodli volby“. V modelu, v němž srovnal skutečný výsledek voleb s hypotetickým (při volební účasti věkových skupin $\mathrm{v}$ roce 2006), se ukazuje, že volby by dopadly takřka stejně: zvýšená volební účast mladých a snížená účast starších lidí by podle modelu vedla $\mathrm{k}$ celkové změně volebních výsledků asi $01,5 \%{ }^{22}$

Můžeme však nalézt i hodnocení videa jako počinu spíše neúspěšného. Ze strany některých marketingových expertů zaznívá kritika neoriginality spotu. Přemluv bábu je považováno za nepovedenou kopii původního spotu Silvermanové. Podle Petra Václavka chybí české verzi ve srovnání s videem Sarah Silvermanové dostatečný nadhled a vtip, Tomáš Mrkvička upozornil na vyšší konfliktnost české verze kampaně oproti Silvermanové. ${ }^{23}$

Druhý typ velmi důrazné kritiky videa přichází od autorů zabývajících se sociologií stáří. Ti upozorňují na to, že video využívá při prezentaci seniorů stereotypizující a negativní vzorce, čímž přispívá k eskalaci mezigeneračních sporů a posiluje předsudky vůči starým lidem. Autoři videa se podle nich dopouštějí tzv. ageismu - věkové diskriminace založené na

21 Srovnej Linek (2012a, s. 24).

22 Srovnej Linek (2012b, s. 84-85).

23 Srovnej Krupka (2010), Slížek (2010). 
přesvědčení o kvalitativní nerovnosti jednotlivých fází lidského života. ${ }^{24}$

Podle Erdmana E. Palmora existují typické negativní předsudky týkající se starých lidí, jako je nemoc, impotence, ošklivost, pokles duševních schopností, duševní choroba, zbytečnost, izolace, chudoba, deprese, politická moc. ${ }^{25}$ Podle Pokorné autoři videa Přemluv bábu tyto negativní stereotypy pro prezentaci seniorů využívají, a dokonce některé prohlubují: negativní zobrazování starých osob není aplikováno pouze na bezejmennou masu důchodců, ale na vlastní blízké příbuzné, dochází nejen k opakování známých stereotypů, ale je přidán relativně nový - v českém kontextu do té doby málo akcentovaný - předsudek ohledně politické síly seniorů. ${ }^{26}$

Video vyvolalo rozporuplné reakce a jeho komplexní hodnocení se zdá být mimořádně obtížné. $\mathrm{V}$ příspěvcích tohoto čísla se zabýváme výzkumem pouze jediného aspektu videa: totiž jeho argumentační či persvazivní složky, které dosud nebyla věnována velká pozornost. Jsme tedy schopni posoudit charakter a potenciální úspěšnost předložené argumentace. Jak se pokusíme ukázat, přijaté výchozí teoretické perspektivy nás vedou k preferenci odlišných výzkumných problémů, formulaci odlišných výzkumných otázek, odlišným způsobům uchopení i hodnocení videa. Společně však mohou různé náhledy na argumentaci nabídnout plastičtější pohled na komplexitu přesvědčování a roli jeho jednotlivých aspektů.

\section{Literatura}

Anýž, D., Honzejk, P. \& Šilpoch, J. (2010): „Režisér Petr Zelenka: Paroubek je nový diktátor. A Češi to nechápou. "Hospodářské noviny [online]. 30. 4. 2010 [cit. 8. 11. 2018]. Dostupné z: https://domaci.ihned.cz/c1-43040390-paroubek-je-novydiktator-a-cesi-to-nechapou.

Budínský, J. (2010): Politický marketing a užití prvků politainmentu ve volbách do PSP ČR 201O. Bakalářská práce. Univerzita Tomáše Bati ve Zlíně, Fakulta multimediálních komunikací, Zlín. 
ČSFD. (2018): „Přemluv bábu.“ In ČSFD.cz. Česko-Slovenská filmová databáze [online]. POMO Media Group, Praha. [cit. 8. 11. 2018]. Dostupné z: https://www.csfd.cz/film/277667-premluv-babu/ komentare/.

van Eemeren, F. H. (2009): „Argumentation theory after the New Rhetoric." L'analisi linguistica e letteraria 17 (1): 119-148.

Issová, M., Mádl, J., \& Zelenka, P. (2010): „Přemluv bábu.“ In Youtube [online]. 22. 4. 2010 [cit. 8. 11. 2018]. Dostupné z: https://www. youtube.com/watch?v=MLfFhdcXJhA.

Klein, O. (2007): Argumentace v komunikaci: (průzkum komunikačního pojetí argumentu). Univerzita Karlova v Praze, Praha.

Komárek, M. (2006): „KSČSSD: Strašák? Ne. Hrozba.“ Idnes [online]. 1. 6. 2010 [cit. 8. 11. 2018]. Dostupné z: https:// zpravy.idnes.cz/kscssd-strasak-ne-hrozba-oxo-/domaci. aspx?c=A060531_194452_nazory_zra.

Kopecký, J. (2010): „Klaus jmenoval Nečasovu vládu. Hlasování o důvěre bude 10. srpna.“ Idnes [online]. 13. 7. 2010 [cit. 8. 11. 2018]. Dostupné z: https://zpravy.idnes.cz/klaus-jmenovalnecasovu-vladu-hlasovani-o-duvere-bude-10-srpna-pud-/ domaci.aspx?c=A100713_100007_domaci_kop.

Kratochvíl, L. \& Procházková, M. (2010): „Mádl a Issová: Takový ohlas na bábu jsme nečekali, ale nelitujeme." Idnes [online]. 26. 4. 2010 [cit. 8. 11. 2018]. Dostupné z: https://zpravy.idnes.cz/madla-issova-takovy-ohlas-na-babu-jsme-necekali-ale-nelitujemepbj-/domaci.aspx?c=A100426_170334_domaci_taj.

Krupka, J. (2010): „Přemluv bábu, at volí pravici, ř́kají Mádl s Issovou v ,ukradeném" klipu." Lidovky [online]. 23. 4. 2010 [cit. 8. 11. 2018]. Dostupné z: https://www.lidovky.cz/domov/premluvbabu-at-voli-pravici-rikaji-madl-s-issovou-v-ukradenem-klipu. A100423_095325_ln_domov_spa.

Lebeda, T., Linek, L., Lyons, P. \& Vlachová, K. (2007): „Úvod.“ In Voliči a volby 2006, ed. T. Lebeda, L. Linek, P. Lyons \& K. Vlachová, Sociologický ústav AV ČR, Praha, s. 1-14. 
Linek, L. (2012a): „Úvod: Volební výsledky, účast a vzorce podpory politických stran." In Voliči a volby 201O, ed. L. Linek, Sociologické nakladatelství, Praha, s. 12-29.

Linek, L. (2012b): „Volební účast mladých a její vliv na volební výsledky." In Voliči a volby 2010, ed. L. Linek, Sociologické nakladatelství, Praha, s. 63-86.

Liška, O. \& Šiklová, J. (2010): „Přemluv bábu! Strana Zelených.“ In Youtube [online]. 26. 4. 2010 [cit. 8. 11. 2018]. Dostupné z: https://www.youtube.com/watch?v=6ghvkK_Ijxc\&t=3s.

Mates, J. (2007): „Proč ODS ztrácí voliče? Lidé se bojí zdražení.“ Idnes [online]. 8. 11. 2007 [cit. 8. 11. 2018]. Dostupné z: https:// zpravy.idnes.cz/proc-ods-ztraci-volice-lide-se-boji-zdrazeni-fz4-/ domaci.aspx?c=A071107_213842_domaci_mia\&fbclid=IwAR33 NnsSySSXXwr7X5FMaQnAsaI-cOM7pb7kiaKOuoWHj7XNaCeq 2ShZogs.

Palmore, E. B. (1999): Ageism: Negative and Positive. Springer Publishing Company, New York.

Pehe, J. (2009): „ODS bude znovu mobilizovat proti KSČSSD.“ In Český rozhlas [online]. 6. 8. 2009 [cit. 8. 11. 2018]. Dostupné z: https://www.rozhlas.cz/cro6/komentare/_zprava/ods-budeznovu-mobilizovat-proti-kscssd--617066.

Perelman, Ch. \& Olbrechts-Tyteca, L. (1969): The New Rhetoric: A treatise on argumentation. University of Notre Dame Press, Notre Dame.

Perelman, Ch. \& Olbrechts-Tyteca, L. (1958): Traité de l'argumentation: La nouvelle rhétorique. Presses universitaires de France, Paris.

Picha, M. (2014): Kritické myšlení a rekonstrukce argumentu. Masarykova univerzita, Brno.

Pobořilová, A. (2009): „Topolánkova vláda padla.“ In ČT24 [online]. 24. 3. 2009 [cit. 8. 11. 2018]. Dostupné z: http://www.ct24.cz/ domaci/49481-topolankova-vlada-padla/.

Pokorná, K. (2015): Jak se aktivní senioři vyrovnávají se stereotypizací. Diplomová práce. Univerzita Karlova, Fakulta sociálních věd, Praha. 
Prokop, D. \& Ř́hová, B. (2009): „Klaus jmenoval novou vládu.

Nastupujeme z běhu, dodal Fischer." Idnes [online]. 8. 5. 2009

[cit. 8. 11. 2018]. Dostupné z: https://zpravy.idnes.cz/klausjmenoval-novou-vladu-nastupujeme-z-behu-dodal-fischer-ple-/ domaci.aspx?c=A090508_072457_domaci_js.

[Rubeš, J. \& Stýblo, Č.] (2010): „Zabij bábu!“ In Youtube [online]. 27. 4. 2010 [cit. 8. 11. 2018]. Dostupné z: https://www.youtube.com/ watch?v=B_Q59QE9M98.

Řiháček, T., Čermák, I. \& Hytych, R. (2013): Kvalitativní analýza textů: čtyři př́stupy. Masarykova univerzita, Brno.

Silverman, S. (2008): „Sarah Silverman and The Great Schlep.“ In Youtube [online]. 25. 9. 2008. [cit. 8. 11. 2018]. Dostupné z: https://www.youtube.com/watch?v=AgHHX9R4Qtk.

Slížek, D. (2010): „Volební deník: Přemluv bábu! je horší kopie vtipu z USA.“ Aktuálně.cz [online]. 23. 4. 2010 [cit. 8. 11. 2018]. Dostupné z: https://zpravy.aktualne.cz/domaci/volebni-denikpremluv-babu-je-horsi-kopie-vtipu-z-usa/r i:article:666616/.

STEM. (2010): „Tisková zpráva STEM 17. 5. 2010: STEM - Preference politických stran květen 2010." In STEM [online]. 17. 5. 2010 [cit. 8. 11. 2018]. Dostupné z: https://www.stem.cz/stranickepreference-kveten-2010/.

Toulmin, S. E. (1976): Knowing and acting. An invitation to philosophy. Macmillan, New York.

Toulmin, S. E. (1958): The Uses of Argument. Cambridge University Press Cambridge.

Vidovićová, L. (2008): Stárnutí, věk a diskriminace - nové souvislosti. Masarykova univerzita, Brno.

Vidovićová, L. \& Honelová, M. (2018): „A Case Study of Ageism in Political Debates: Are Social Media a Latent Source of Generational Harted?" Slovenský národopis 66 (2): 203-220.

Wertz, F. J., Charmaz, K., McMullen, L. M., Josselson, R., Anderson, R. \& McSpadd, E. (2011): Five ways of doing qualitative analysis: Phenomenological psychology, grounded theory, discourse analysis, narrative research, and intuitive inquiry. Guilford Press, New York. 


\begin{abstract}
Abstrakt
Editorial stručně shrnuje obsah monotematického čísla, $v$ němž jde o teoretické představení pěti přístupů $\mathrm{k}$ analýze argumentačního textu (neoaristotelský přístup, Toulminův model, př́stup neformální logiky, pragma-dialektiky a kritické diskurzivní analýzy) a o ilustraci prostřednictvím aplikací těchto př́stupů na konkrétní materiál. Ve všech textech čísla je jako společný materiál pro analýzu zvolen videoklip Přemluv bábu (2010). Editorial nabízí představení videa: jeho přepis, historický kontext a zhodnocení dosavadních pohledů na jeho přesvědčivost.
\end{abstract}

Klíčová slova: argumentace, analýza, Přemluv bábu

\title{
Abstract \\ The Approaches to the Analysis of Argumentative Text. Editorial
}

The editorial briefly summarizes the content of a special issue, which deals with the theoretical introduction of five approaches to argumentative text analysis (neo-aristotelian approach, Toulmin's model, informal logic, pragma-dialectics, and critical discoursive analysis), and their illustration by applying these approaches to specific material. A video, Přemluv bábu (Convince your grandma, 2010), is chosen as the material to analyze in all texts. The editorial offers an introduction to the video: its transcription, historical context, and an evaluation of previous perspectives on its persuasiveness.

Key words: argumentation, analysis, Convince your grandma

Svačinová, I. (2018): „Přístupy k analýze argumentačního textu.“ Fỉlosofie dnes 10(2): 4-17. Dostupné z www.filosofiednes.ff.uhk.cz 